Brit. J. industr. Med., 1961, 18, 277.

\title{
FURTHER STUDIES ON THE TOXICITY OF SOME TETRA AND TRIALKYL LEAD COMPOUNDS
}

\author{
BY \\ JILL E. CREMER and S. CALLAWAY \\ From The Toxicology Research Unit, M.R.C. Laboratories, Carshalton, Surrey, and The War Office Chernical Defence \\ Experimental Establishment, Porton Down, Salisbury, Wilts
}

(RECEIVED FOR PUBLICATION MAY 18, 1961)

The toxicity of tetra and trimethyl and propyl lead compounds has been studied after their administration to rats and rabbits. The toxicity to rats of tetramethyl lead has been compared with tetraethyl lead when given by inhalation.

Both tetramethyl and tetrapropyl lead were found to be considerably less toxic than trimethyl and tripropyl lead. There was evidence of a slow rate of conversion of the tetra to the trialkyl lead forms in rats in vivo.

Although there was a distinct difference between the signs of poisoning seen after giving the methyl or the propyl lead compounds the primary site of action for both groups appeared to be the central nervous system.

Some biochemical studies using slices of rat brain cortex showed that trimethyl and tripropyl lead inhibited the oxidation of glucose whereas tetramethyl and tetrapropyl lead were a hundred times less active in this respect.

In a previous paper (Cremer, 1959) some biochemical studies on the toxicity of tetraethyl lead were described. The present paper reports similar work with tetra and trimethyl lead and tetra and tripropyl lead.

Because of its toxic properties towards man the importance of care in handling tetraethyl lead is well known. Recent developments in the petroleum industry have shown that tetramethyl lead is likely to become of importance as an improved anti-knock additive. Some preliminary studies on its toxicity in laboratory animals have therefore been undertaken together with studies on closely related compounds.

\section{MATERIALS AND METHODS}

Pure samples of the lead compounds were supplied by Mr. G. F. Harrison, of The Associated Ethyl Company Ltd., Ellesmere Port, Cheshire and by Professor R. A. Kehoe, The Kettering Laboratory, Department of Preventive Medicine and Industrial Health, College of Medicine, University of Cincinnati, Cincinnati, Ohio.

Adult albino rats of 175 to $230 \mathrm{~g}$. and rabbits of $2 \cdot 5$ to $3.0 \mathrm{~kg}$. body weight were used.

Administration of Lead Compounds in Animals

Intravenous injections of tetramethyl lead were given to rats (tail vein) and rabbits (ear vein) as a solution in

4 ethanol. Each rat received not more than $0.05 \mathrm{ml}$. and each rabbit not more than $0.2 \mathrm{ml}$. of the solution. Oral administration of the alkyl lead compounds to rats was by stomach tube. Tetramethyl and tetrapropyl lead were dissolved in arachis oil. Tripropyl lead chloride was dissolved in one part dimethyl formamide and two parts arachis oil.

Trimethyl lead chloride was given to rats and rabbits by intraperitoneal injection as a solution in $0.9 \% \mathrm{NaCl}$. Tripropyl lead chloride was given to rats by intraperitoneal injection as a solution in glycerol formol.

The inhalation exposures were carried out in an allglass chamber. Groups of four rats were exposed simultaneously and the apparatus was designed so that only the heads of the rats were in contact with the vapour. Pure solutions of tetramethyl and tetraethyl lead were injected into the chamber by a mechanically driven syringe. The air-flow was maintained at 50 litres per minute. Samples of air were taken at intervals during the 60-minute exposure period into Neal bubblers at approximately 1 litre per minute through accurately calibrated critical orifices. The bubblers contained $5 \mathrm{ml}$. of 100-200 petroleum ether.

Estimation of Trialkyl Lead Compounds and Inorganic Lead

The trialkyl lead compounds were estimated by the dithizone procedure (Cremer, 1959). Neither tetra- 
methyl nor tetrapropyl lead formed a coloured complex with dithizone.

The petroleum ether containing tetra-alkyl lead compounds trapped in the bubblers was washed into $100 \mathrm{ml}$. flasks, using 1 or $2 \mathrm{ml}$. of petroleum ether, and $5 \mathrm{ml}$. concentrated hydrochloric acid were added. The mixture was shaken for five minutes and then placed in a boiling water bath for $\mathbf{3 0}$ minutes. The aqueous layer was made up to $100 \mathrm{ml}$. with distilled water and the remaining petroleum ether was sucked off. The resulting solution of lead chloride was estimated polarographically. This method was modified from Milner (1957).

The lethal doses and their $95 \%$ confidence limits were calculated by the method of Weil (1952).

The procedure for studying the metabolism of glucose by slices of rat brain cortex was exactly as described previously (Cremer, 1959). Details are given in the legend to Table 4.

\section{RESULTS}

\section{Action of Organo-lead Compounds in vivo}

Toxicity to Rats.-Summaries of the response of rats to the different lead compounds are given in Tables 1 and 2. Within a few minutes of receiving intraperitoneal injections of trimethyl lead chloride the rats were lying stretched out with paresis of the hind legs. The ears and tails were very pale. These signs largely disappeared 40 minutes later, giving way to general signs of toxicity; the animals sat quietly with staring coats. Rats which did not die within the first two hours but which received lethal doses became hyperexcitable and irritable with sparring behaviour. Generalized body tremors appeared which became increasingly severe with occasional convulsions. Some animals exhibited marked tremors for as long as $\mathbf{2 4}$ hours before death.

Tetramethyl lead was appreciably less toxic to rats than trimethyl lead. Because of the toxicity of the solvent the maximum dose given by intravenous injection was about $34 \mathrm{mg}$. $/ \mathrm{kg}$. No signs of poisoning appeared in rats receiving this dose. Higher doses of tetramethyl lead which were given orally, produced signs of poisoning identical with those produced by trimethyl lead chloride.

After exposure by inhalation to the highest concentration of tetramethyl lead $(9.84 \mathrm{mg}$./litre for 60 minutes) no obvious signs of intoxication were seen beyond a mild hyperexcitability. The death of one rat with bronchopneumonia was not thought to be attributable to tetramethyl lead. The development of signs of poisoning after inhalation of tetraethyl lead followed a pattern identical with that described after giving tetraethyl lead intravenously (Cremer, 1959). The hyperexcitable state and continuous generalized body tremors seen in these animals were the same as those seen in rats poisoned with trimethyl lead chloride or high doses of tetramethyl lead.

Rats given tripropyl lead chloride responded differently from those given trimethyl or triethyl lead chloride. After an intraperitoneal dose of $20 \mathrm{mg} . / \mathrm{kg}$. the rats showed almost immediate signs of uneasiness and at four hours two out of a group of four rats were weak with an unsteady gait. One of these two rats died overnight and the other became steadily weaker especially in the hind legs, and died quietly 28 hours after the injection. The remaining two rats became very irritable and developed a characteristic gait with stiff back legs, a humped back and the tail held high. The rats remained in this condition for six days after which they regained a normal posture and movement. After giving higher doses of tripropyl lead orally a similar response was seen. Definite weakness of the hind limbs was a constant feature and rats which became weak had difficulty in remaining in an upright position when they closed their eyes. In rats given up to $40 \mathrm{mg}$. $/ \mathrm{kg}$. of tetrapropyl lead intravenously, no signs of poisoning were seen. Four rats given a high oral dose of tetrapropyl lead (395 mg./kg.) developed signs of poisoning identical with those seen after giving tripropyl lead. Tremors and convulsions were not seen after giving the propyl lead compounds.

Toxicity to Rabbits.-Two adult rabbits were given trimethyl lead chloride by intraperitoneal injection. The doses were 7.5 and $15 \mathrm{mg}$. $/ \mathrm{kg}$. Both rabbits showed an immediate response of lying stretched out with a wriggling body movement. The rabbit which received the higher dose died 12 hours after injection. During the first week the remaining rabbit appeared to be hyperaesthetic when handled around the head but this reaction became less marked during the following two weeks and the animal seemed otherwise normal.

Two adult rabbits were injected intravenously with tetramethyl lead at 20 and $40 \mathrm{mg}$. $/ \mathrm{kg}$. No signs of poisoning could be discerned during a three-week period following the injections. A rabbit injected intravenously with tetraethyl lead $(31 \mathrm{mg} . / \mathbf{k g}$.) showed immediate signs of distress with very rapid breathing and stretching out in its cage. It died unobserved approximately 16 hours after injection.

\section{Distribution of Organo-lead Compounds in Rats}

The dithizone method used for estimating trialkyl lead compounds in tissues specifically measures the complete trialkyl lead ions without interference from tetra or dialkyl lead or inorganic lead ions.

The distribution of trimethyl lead and tripropyl lead in certain tissues of rats killed four hours and 
TABLE 1

TOXICITY OF ORGANO-LEAD COMPOUNDS TO RATS

\begin{tabular}{|c|c|c|c|c|c|c|c|}
\hline Compound & $\begin{array}{c}\text { No. of } \\
\text { Animals }\end{array}$ & $\underset{(\mathrm{mg} . / \mathrm{kg} .)}{\text { Dose }}$ & Route & Reactions & Death & $\begin{array}{l}\text { Time of } \\
\text { Death After } \\
\text { Injection } \\
\text { (days) }\end{array}$ & $\underset{\text { (mg./kg.) }}{\mathbf{L D}_{\mathrm{se}}}$ \\
\hline Tetramethyl lead & $\begin{array}{l}4 \\
4 \\
4 \\
4 \\
4 \\
4 \\
4\end{array}$ & $\begin{array}{l}26 \\
34 \cdot 3 \\
62 \cdot 5 \\
125 \\
250 \\
500\end{array}$ & $\begin{array}{l}\text { I.V. } \\
\text { I.V. } \\
\text { Orally } \\
\text { Orally } \\
\text { Orally } \\
\text { Orally }\end{array}$ & $\begin{array}{l}\text { No signs of poisoning } \\
\text { No signs of poisoning } \\
\text { Loss of weight during first week, thereafter } \\
\text { regained weight } \\
\text { Tremors developed after three days; sur- } \\
\text { viving rat became ill with altered gait, } \\
\text { but gradually returned to normal } \\
\text { behaviour } \\
\text { Very excitable behaviour, sparring, tremors, } \\
\text { and convulsions } \\
\text { Tremors developed after } 24 \text { hours }\end{array}$ & $\begin{array}{l}\mathbf{0} \\
\mathbf{0} \\
\mathbf{0} \\
\mathbf{3}\end{array}$ & $\begin{array}{l}4 \\
2 \text { and } 3\end{array}$ & $\begin{array}{l}109 \cdot 3 \\
(77 \cdot 43-154 \cdot 5)\end{array}$ \\
\hline Tripropyl lead chloride & $\begin{array}{l}4 \\
4\end{array}$ & 20 & $\begin{array}{l}\text { I.P. } \\
\text { I.P. } \\
\text { I.P. } \\
\text { Orally } \\
\text { Orally }\end{array}$ & $\begin{array}{l}\text { No signs of poisoning } \\
\text { Lost weight during first few days, there- } \\
\text { after surviving rats regained weight; all } \\
\text { rats showed humped back gait but three } \\
\text { gradually returned to normal } \\
\text { One rat became weak within three hours } \\
\text { after injection and remained so until } \\
\text { death; the two surviving rats had } \\
\text { altered gait but returned gradually to } \\
\text { normal; some initial weight loss } \\
\text { After two days all four rats looked ill and } \\
\text { had altered gait; two rats became } \\
\text { weaker; remaining two rats gradually } \\
\text { improved } \\
\text { Between } 24 \text { and } 72 \text { hours all rats became } \\
\text { very weak with unsteady gait }\end{array}$ & $\begin{array}{l}0 \\
1\end{array}$ & $\begin{array}{l}2 \\
1 \text { and } 2 \\
4 \text { and } 7 \\
3 \text { to } 6\end{array}$ & $\begin{array}{r}26.67 \\
\text { (approximate } \\
\text { value) }\end{array}$ \\
\hline Tetrapropyl lead & $\begin{array}{l}4 \\
4 \\
4\end{array}$ & $\begin{array}{l}30 \cdot 8 \\
40 \\
395\end{array}$ & $\begin{array}{l}\text { I.V. } \\
\text { I.V. } \\
\text { Orally }\end{array}$ & $\begin{array}{l}\text { No signs of poisoning } \\
\text { No signs of poisoning } \\
\text { After } 48 \text { hours the rats looked ill with a } \\
\text { weakness of the hind legs; weakness } \\
\text { became more generalized until death }\end{array}$ & $\begin{array}{l}0 \\
0 \\
4\end{array}$ & 3 to 4 & \\
\hline
\end{tabular}

TABLE 2

A COMPARISON OF THE TOXICITY TO RATS OF TETRAMETHYL AND TETRAETHYL LEAD GIVEN BY INHALATION

\begin{tabular}{|c|c|c|c|c|c|}
\hline Compound & 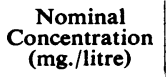 & $\begin{array}{c}\text { Analysis } \\
\text { Mean Range } \\
\text { (mg./litre) }\end{array}$ & Reactions & Deaths & $\begin{array}{c}\text { Approximate } \\
\text { Dose } \\
\text { (mg./kg.)* }\end{array}$ \\
\hline Tetraethyl lead & $\begin{array}{l}4 \cdot 84 \\
2 \cdot 77 \\
1.58 \\
0.77 \\
\\
0.27 \\
0 \cdot 19 \\
0.095\end{array}$ & $\begin{array}{l}3.87(3 \cdot 3-4 \cdot 4) \\
2 \cdot 64(2 \cdot 6-2 \cdot 9) \\
1.50(1 \cdot 32-1 \cdot 69) \\
0.66(0 \cdot 57-0 \cdot 74) \\
\\
0 \cdot 34(0 \cdot 32-0 \cdot 39) \\
0 \cdot 17(0 \cdot 15-0 \cdot 18) \\
0.08\end{array}$ & $\begin{array}{l}\text { Eight rats died in under six hours and remaining rats died in } \\
\text { under } 12 \text { hours; intensely cyanotic at death } \\
\text { All died in less than } 24 \text { hours } \\
\text { Three died in } 24 \text { hours; remaining rats died in under } 72 \text { hours } \\
\text { All rats showed excitable sparring behaviour; one rat died } \\
\text { after two days; two rats showed continuous tremors leading } \\
\text { to death in } 14 \text { days } \\
\text { All affected with mild signs of poisoning with slow recovery } \\
\text { All affected with mild signs of poisoning with slow recovery } \\
\text { Very mild signs of poisoning from which recovery was made }\end{array}$ & $\begin{array}{r}12 / 12 \\
20 / 20 \\
16 / 16 \\
3 / 16 \\
\\
0 / 20 \\
0 / 16 \\
0 / 16\end{array}$ & $\begin{array}{c}232 \\
158 \\
90 \\
39 \cdot 6 \\
\\
20.4 \\
10 \cdot 2 \\
4.8\end{array}$ \\
\hline Tetramethyl lead & $\begin{array}{l}4.92 \\
2 \cdot 41\end{array}$ & $\begin{array}{l}8 \cdot 87(8 \cdot 42-9 \cdot 26) \\
4 \cdot 48(4 \cdot 37-4 \cdot 78) \\
2 \cdot 18(2 \cdot 07-2 \cdot 29)\end{array}$ & $\begin{array}{l}\text { One rat died after } 16 \text { days; macroscopical examination sug- } \\
\text { gested a bronchopneumonia of unknown origin; a mild } \\
\text { hyperexcitability seen in all rats but no other obvious signs } \\
\text { of intoxication } \\
\text { No obvious signs of intoxication other than a mild hyper- } \\
\text { excitability } \\
\text { No obvious signs of poisoning }\end{array}$ & $\begin{array}{l}0 / 12 \\
0 / 16\end{array}$ & $\begin{array}{l}269 \\
131\end{array}$ \\
\hline
\end{tabular}

Assuming a probit slope of about 8 the $L C_{s 0}$ for tetraethyl lead is approximately 0.85 mg./litre (based on the analytical concentration of tetraethyl lead). For tetramethyl lead the $L^{2} C_{s 0}$ is higher than $8.87 \mathrm{mg}$./litre.

*The approximate dose of the tetra-alkyl lead compounds has been calculated as $\mathrm{mg}$. $/ \mathbf{k g}$. body weight based on an average air intake for a rat of $100 \mathrm{ml} . / 100 \mathrm{~g}$. body weight/minute. 
TABLE 3

DISTRIBUTION OF TRIMETHYL AND TRIPROPYL LEAD IN RATS GIVEN EITHER TRI- OR TETRA-ALKYL LEAD

\begin{tabular}{|c|c|c|c|c|c|c|}
\hline \multirow{2}{*}{ Compound } & \multirow{2}{*}{$\underset{\text { (mg./kg.) }}{\text { Dose }}$} & \multirow{2}{*}{$\begin{array}{l}\text { Time Killed } \\
\text { After Injection } \\
\text { (hours) }\end{array}$} & \multicolumn{4}{|c|}{ Trialkyl Lead Compound Found ( $\mu \mathrm{g} . / \mathrm{g}$. or $\mathrm{ml}$. wet wt.) } \\
\hline & & & Blood & Liver & Kidney & Brain \\
\hline $\begin{array}{l}\text { Trimethyl lead chloride } \\
\text { Tetramethyl lead } \\
\text { Tripropyl lead chloride } \\
\text { Tetrapropyl lead }\end{array}$ & $\begin{array}{l}15 \\
15 \\
40 \\
40 \\
10 \cdot 5 \\
10 \cdot 5 \\
10 \cdot 5 \\
40\end{array}$ & $\begin{array}{r}4 \\
24 \\
4 \\
24 \\
2 \\
4 \\
24 \\
24\end{array}$ & $\begin{array}{c}160 \\
180 \\
3 \cdot 7 \\
22 \\
0 \\
3 \cdot 9 \\
1 \cdot 1 \\
0\end{array}$ & $\begin{array}{r}40 \\
28 \cdot 5 \\
6 \cdot 7 \\
10 \cdot 2 \\
10 \cdot 7 \\
29 \cdot 5 \\
20 \cdot 0 \\
13 \cdot 2\end{array}$ & $\begin{aligned} 23 \\
25 \cdot 5 \\
1.9 \\
1.9 \\
3.3 \\
19.0 \\
19 \cdot 0 \\
7.4\end{aligned}$ & $\begin{array}{l}2 \cdot 25 \\
4 \cdot 3 \\
0 \\
0 \\
= \\
= \\
0.5\end{array}$ \\
\hline
\end{tabular}

24 hours after intraperitoneal injection of the respective lead compounds is given in Table 3. The highest concentrations of trimethyl lead were found in the blood, but appreciable quantities were also present in liver and kidney. The amount in the brain was very low. In contrast to the trimethyl and triethyl lead (Cremer, 1959) only trace amounts of tripropyl lead were found in blood. The reason for this is not known, for, when trimethyl, ethyl, and propyl lead chlorides were added separately to whole rat blood in vitro over $90 \%$ of each compound was recovered from the red cells.

\section{Conversion of Tetra to Trialkyl Leads in Rats}

It was previously found that within four hours of injecting rats with tetraethyl lead large amounts of triethyl lead could be found in their tissues. In vitro studies showed that rat liver preparations were able to bring about a rapid conversion of tetra- to triethyl lead (Cremer, 1959).

When rats were killed four hours after an injection of tetramethyl lead and several tissues analysed for trimethyl lead only small amounts were found (Table 3). After 24 hours the amount of trimethyl lead in the blood and liver had increased but was still indicative of a fairly slow rate of conversion of tetramethyl lead compared with tetraethyl lead. Similarly, after giving rats $40 \mathrm{mg}$. $/ \mathrm{kg}$. tetrapropyl lead the amount of tripropyl lead found in the tissues was less than that found after giving $10.5 \mathrm{mg} . / \mathrm{kg}$. of tripropyl lead chloride (Table 3).

\section{Effect of Organo-lead Compounds on Slices of Rat-brain Cortex}

Preparations of rat-brain cortex slices were incubated in Kreb's Ringer phosphate medium with glucose as substrate with and without added organolead compounds. Measurements were made of the oxygen consumption and the levels of lactate and pyruvate. The results are given in Table 4. Both trimethyl lead and tripropyl lead inhibited oxygen uptake, lowered the level of pyruvate and increased the level of lactate. This metabolic change indicated a block in the respiratory pathway whereby pyruvate formed from glucose is normally completely oxidized with the synthesis of high energy phosphate compounds. The glycolytic pathway of glucose catabolism was not inhibited so that lactic acid accumulated. The same type of inhibition of glucose metabolism had been found with triethyl lead. Neither tetramethyl nor tetrapropyl lead affected glucose metabolism by brain slices except when added in high concentrations (Table 4).

Activity of Brain Slices Prepared from Rats given Organo-lead Compounds.-It has already been shown that the glucose metabolism of brain slices given either tetra- or triethyl lead was inhibited in the same way as when triethyl lead was added in vitro. Brain slices prepared from rats given tripropyl lead showed a marked inhibition of glucose metabolism, but slices prepared from rats given tetra-

TABLE 4

EFFECT OF ALKYL LEAD COMPOUNDS ADDED IN VITRO ON THE METABOLISM OF SLICES OF RAT BRAIN CORTEX

\begin{tabular}{|c|c|c|c|c|}
\hline \multirow[b]{2}{*}{ Compound } & \multirow{2}{*}{$\stackrel{\text { Molar }}{\text { Concentration }}$} & \multicolumn{3}{|c|}{$\%$ of Control } \\
\hline & & $\mathrm{QO}_{2}{ }^{*}$ & $\begin{array}{l}\text { Lactic } \\
\text { Acid }\end{array}$ & $\begin{array}{c}\text { Pyruvic } \\
\text { Acid }\end{array}$ \\
\hline $\begin{array}{l}\text { Trimethyl lead } \\
\text { chloride }\end{array}$ & $\begin{array}{l}8.8 \times 10^{-6} \\
1.45 \times 10^{-5} \\
5.8 \times 10^{-5} \\
1.5 \times 10^{-4} \\
7.5 \times 10^{-4}\end{array}$ & $\begin{array}{r}145 \\
73 \\
36 \\
100 \\
100\end{array}$ & $\begin{array}{l}150 \\
350 \\
360 \\
119 \\
139\end{array}$ & $\begin{array}{r}100 \\
57 \\
32 \\
100 \\
100\end{array}$ \\
\hline $\begin{array}{l}\text { Tripropyl lead } \\
\text { chloride }\end{array}$ & $\begin{array}{l}2.4 \times 10^{-7} \\
4.8 \times 10^{-7} \\
1.9 \times 10^{-6} \\
7.0 \times 10^{-5}\end{array}$ & $\begin{array}{r}116 \\
80 \\
41 \\
118\end{array}$ & $\begin{array}{l}170 \\
340 \\
240 \\
135\end{array}$ & $\begin{array}{r}100 \\
53 \\
32 \\
100\end{array}$ \\
\hline
\end{tabular}

* Oxygen uptake.

Each flask contained $3.0 \mathrm{ml}$. of Kreb's Ringer phosphate solution with glucose $0.011 \mathrm{M}$, tissue slice of $50-60 \mathrm{mg}$. wet wt., and $0.2 \mathrm{ml}$. of $20 \%(\mathrm{w} / \mathrm{v}) \mathrm{KOH}$ in the centre well for absorption of $\mathrm{CO}$. The gas phase was $100 \% \mathrm{O}_{2}$. Incubation was at $37^{\circ} \mathrm{C}$. for 75 minutes. QO, was calculated as $\mu \mathrm{l}$. of $\mathrm{O}_{2} / \mathrm{mg}$. dry weight of tissue/hour. The control $\mathrm{OO}$, value was 12.6. The control values for lactic acid and pyruvic acid were $179 \mu \mathrm{g}$. and $9.0 \mu \mathrm{g}$. respectively, estimated as the amount present in the medium after 75 minutes incubation. 
TABLE 5

ACTIVITY OF BRAIN SLICES PREPARED FROM RATS GIVEN ALKYL LEAD COMPOUNDS

\begin{tabular}{c|c|c|c|c|c}
\hline Compound & $\begin{array}{c}\text { Dose } \\
\text { (mg./kg.) }\end{array}$ & $\begin{array}{c}\text { Time } \\
\text { Killed } \\
\text { After In- } \\
\text { jection } \\
\text { (hours) }\end{array}$ & \multicolumn{2}{|c|}{ Brain Slices (\% of Control) } \\
\cline { 5 - 6 } & QO2 & $\begin{array}{c}\text { Lactic } \\
\text { Acid }\end{array}$ & $\begin{array}{c}\text { Pyruvic } \\
\text { Acid }\end{array}$ \\
\hline $\begin{array}{c}\text { Trimethyl lead } \\
\text { chloride }\end{array}$ & 30 & 24 & 113 & 90 & 100 \\
$\begin{array}{c}\text { Tripropyl lead } \\
\text { chloride }\end{array}$ & 30 & 48 & 100 & 110 & 120 \\
& $10 \cdot 5$ & 2 & 98 & 96 & 115 \\
$\begin{array}{c}\text { Tetrapropyl } \\
\text { lead }\end{array}$ & $10 \cdot 5$ & 4 & 61 & 280 & 73 \\
\hline & 40.0 & 24 & 110 & 116 & 95 \\
\hline
\end{tabular}

propyl lead varied only slightly from the controls (Table 5). No inhibition of glucose metabolism was found in slices prepared from rats given trimethyl lead even when the animals were showing definite signs of poisoning. This lack of effect might be largely accounted for by the high water solubility of trimethyl lead compared with triethyl or tripropyl lead so that on placing a brain slice in the incubation fluid the trimethyl lead content of the slice redistributes into the medium leaving an insufficient amount in the tissue to inhibit glucose oxidation. It is noticeable that the concentration of trimethyl lead required in vitro to inhibit brain slices is at least 30 times greater than that of tripropyl lead.

\section{DISCUSSION}

The signs of poisoning seen in rats after trimethyl lead chloride administration were very similar to those previously described for triethyl lead chloride poisoning (Cremer, 1959). The pattern of distribution of the two compounds in the tissues of the rats was also very similar. Tetramethyl lead was only toxic when given in relatively high doses; the signs of poisoning then resembled those seen in the rats given trimethyl or tetra or triethyl lead.

Since the hazard to man from these compounds is likely to occur in workers cleaning out petrol storage tanks or in manufacturing plants where the fumes and vapours might be inhaled the results of the inhalation studies on rats described in Table 2 are of particular interest. Tetramethyl lead given by this route had less than one-tenth of the toxicity of tetraethyl lead.

Tripropyl lead chloride provoked signs of poisoning differing in character from, and less well defined than, those seen in trimethyl or triethyl lead poisoned animals. The altered gait seen in many of these animals appeared to be a reversible phenomenon indicating a lack of permanent damage to the central nervous system which is consistent with there being no pathological changes seen on examination of the brains and spinal cords. As with the alkyl tin compounds (Barnes and Stoner, 1958) no permanent damage to cells of the central nervous system has been found in animals given any of the alkyl lead compounds studied in this laboratory.

Tetrapropyl lead, like tetramethyl lead was only toxic when given in relatively high doses.

The few experiments in which rabbits were used showed that they differed little from rats in their sensitivity towards the various alkyl lead compounds.

The most striking difference in the present results from those obtained using tetra and triethyl lead was that whereas tetraethyl lead was almost as toxic as triethyl lead (the $\mathrm{LD}_{50}$ values for rats were 15.4 and $11.2 \mathrm{mg} . / \mathrm{kg}$. respectively) both tetramethyl and tetrapropyl lead were considerably less toxic than the respective tri compounds.

Evidence was previously given (Cremer, 1959) in support of the hypothesis that tetraethyl lead itself is non-toxic but it is rapidly converted enzymically by the liver to triethyl lead which is toxic and to which metabolic processes of brain tissue are particularly sensitive. In the present work there is additional evidence in support of this conception which provides an explanation for the low toxicity of tetramethyl and tetrapropyl lead.

The results given in Table 4 show that both trimethyl and tripropyl lead, when added in vitro, inhibit the oxidation of glucose by slices of brain cortex. Neither tetramethyl nor tetrapropyl lead inhibited glucose oxidation at concentrations a hundred times greater than their trialkyl lead counterparts. Good agreement was previously found between the amount of triethyl lead found in the tissues of rats given just lethal doses of either tetra or triethyl lead which was indicative of a very rapid conversion of the tetra to the tri form. Results given in Table 3 show that the amount of trimethyl or tripropyl lead found in the tissues of rats given retramethyl or tetrapropyl lead was very much less than that found after lethal doses of either tri compound. It thus seems highly probable that the low toxicity of tetramethyl and tetrapropyl lead is directly related to their slow rate of conversion. Pure samples of tetramethyl and tetrapropyl lead decompose at a slower rate than tetraethyl lead when stored. Tetramethyl lead is, however, highly explosive when ignited.

There have been several reports of human casualties suffering from tetraethyl lead poisoning (Cassells and Dodds, 1946; Boyd, Walker, and Henderson, 1957; Morrill, 1960). It is only recently that tetramethyl lead has been used as an additive to petrol and no reports of any human casualties from 
contact with this compound have been found by the authors. From experimental work with laboratory animals it is suggested that the toxicity of the tetraalkyl lead compounds to a particular species is dependent upon the rate at which the species converts the tetra to the trialkyl lead form. Brodie (1956), in a review on the pathways of drug metabolism has pointed out that certain drugs are metabolized at completely different rates in animals compared with man. The metabolic pathway for a particular drug is, however, often the same for several different species. In the present work using rats and rabbits tetramethyl lead appears to be appreciably less toxic than tetraethyl lead but this may not be the case in man. The precautions taken in handling tetraethyl lead should be applied equally to tetramethyl lead.

The lower members of the trialkyl lead compounds are toxic to animals and their action appears to be predominantly on the central nervous system although in sub-lethal doses the changes brought about are not permanent.

We are grateful to Mr. D. Potter and Mr. Lynch for their skilled technical assistance, and to Mr. B. Purser and Mr. M. Wheeler who developed and carried out the analyses for the inhalation experiments.

\section{REFERENCES}

Barnes, J. M., and Stoner, H. B. (1958). Brit. J. industr. Med., 15, 15. Boyd, P. R., Walker, G., and Henderson, I. N. (1957). Lancet, 1, 181. Brodie, B. B. (1956). J. Pharm. Pharmacol., 8, 1.

Cassells, D. A. K. and Dodds, E. C. (1946). Brit. med. J., 2, 681. Cremer, J. E. (1959). Brit. J. industr. Med., 16, 191.

Milner, G. W. C. (1957). Principles and Applications of Polarography. Longmans, Green, London.

Morrill, E. E. (1960). Amer. industr. Hyg. Ass. J., $21,515$.

Weil, C. S. (1952). Biometrics, 8, 249. 